\title{
Imanol Uribe's La muerte de Mikel: Policing the Gaze/Mind the Gap
}

\author{
JO EVANS
}

\author{
University College, London
}

La muerte de Mikel (1983) was the most successful film in a relative boom resulting from increased Basque government subsidies between 1982 and 1987. It was also among the top-grossing Spanish films of $1984 .{ }^{1}$ Like The Crying Game (UK, 1992) and The Kiss of the Spiderwoman (US/Brazil, 1985), it juxtaposes revolutionary politics with homosexuality to examine ideological suppressions of difference. Mikel is an unhappily-married young pharmacist involved in Basque Nationalist politics. At the beginning of the film, his wife Begoña seems concerned to resolve their problems, but Mikel bites her during an alcohol-fuelled attempt at oral sex, effectively terminating their relationship in summary 'castration'. The attack takes place after Mikel discovers that Begoña has discussed their sexual problems with his domineering mother and may be read, therefore, as a horrificallydisplaced attack on the phallic mother which signals the maternal/filial conflict that will lead to Mikel's death.

Begoña's doctor, who is also a friend and mentor to Mikel, recommends a therapist in Bilbao. After his first session, Mikel joins an old friend in a bar, gets drunk and has sex with transvestite Fama. Humiliated and confused, he embarks on a suicidal drive down the wrong side of the motorway, but swerves aside in time to avoid a crash. He does come to terms with his attraction to Fama, and is forgiven by Begoña (in a scene which defies the suspension of female disbelief). However, when his homosexual relationship becomes public, he is rejected by his political

1 For further discussion of the Basque film industry see José Enrique Monterde, Veinte años de cine español (1973-1992): un cine bajo la paradoja (Barcelona: Paidós, 1993), 122-23. Peter Besas discusses the controversy surrounding Uribe's earlier films, El proceso de Burgos (1979) and La fuga de Segovia (1981), in Behind the Spanish Lens: Spanish Cinema under Fascism and Democracy (Denver: Arden Press, 1985), 204-08. J. M. Caparr6s Lera places La muerte de Mikel tenth in a list of the fifty most successful Spanish films prior to 31 December 1987 in El cine español de la democracia: de la muerte de Franco al 'cambio' socialista (19751989) (Barcelona: Anthropos, 1992), 414-16. 
comrades, arrested and questioned about ETA activities. Resisting with dignity the violent attempts of the police to get information out of him, he comes out of prison enthusiastic about developing his relationship with Fama, only to die in bed in his mother's home. His death is not explained, but cinematography points clearly to the mother, who has already stated that she cannot accept the public humiliation of Mikel's homosexual relationship. The black irony of this warped maternal ideology is then bitterly underlined by the way the political comrades who rejected him in life appropriate his death as a forum for political protest.

In the present study I want to examine the role of the Gaze in the interplay of desire and confrontation that leads to Mikel's death. This is a statement of clear allegiance with Lacan, about which I am slightly ambivalent, so before moving on I would like to insert a brief aside. Mikel's therapist comments that he prefers a Groucho Marxist to a straight Marxist therapeutic approach, and I would like to 'inject' a similar note of caution into the Lacanian approach. Lacan does, after all, describe the conscious mind as a reluctant 'Celestina', jealously concealing an exotic beauty (the unconscious) from Lacan's eager and slightly predatory gaze, and this is an exotic beauty he then goes on to discuss using the schema of a round sack filled with fish. ${ }^{2}$ Although this may be read as just another example of the way Lacan illustrates his narrative with religious iconography, it does also lead to speculation on the schema Lacan might have used had he been born female. However, and more seriously, Lacan's comments on the field of the Gaze and the Freudian scopic drive are appealing to anyone trying to analyse film, as is the seductive, almost mystical, intensity of his struggle with the truth of the unconscious as an 'encounter, forever missed [...] between dream and awakening'. ${ }^{3}$ So, with a

2 These, and all subsequent, references to Jacques Lacan are from the English-language edition, The Four Fundamental Concepts of Psycho-analysis, trans. Alan Sheridan (London: Penguin, 1979) (first published as Le Séminaire de Jacques Lacan, Livre XI, "Les Quatre concepts fondamentaux de la psychanalyse' [Paris: Éditions du Seuil, 1973]). Lacan is illuminating on transference, but his choice of metaphor is questionable: To appeal to some healthy part of the subject thought to be there in the real world, capable of judging with the analyst what is happening in the transference, is to misunderstand that it is precisely this part that is concerned in the transference, that it is this part that closes the door, or the window, or the shutters, or whatever-and that the beauty with whom one wishes to speak is there, behind, only too willing to open the shutters again" (131). For the description of the unconscious as a round sack, or 'hoop net', see page 144.

3 I am thinking here of Lacan's narrative style, but the following comment on atheism might be particularly appropriate: 'For the true formula of atheism is not God is dead-even by basing the origin of the function of the father upon his murder, Freud protects the father-the true formula of atheism is God is unconscious' (59). Lacan is at his most appealing when describing the awe inspired in him by the unconscious. See, for example, in the Preface: 'All I can do is tell the truth. No, that isn't so-I have missed it. There is no 
warning to mind the gaps in the Lacanian story, which is also, of course, a pun on the Lacanian description of the field of the Gaze itself as a gap, I want to look at the way the Gaze is 'policed' in this film by the forces which cross ideological boundaries to collude in the confinement and death of Mikel.

\section{The Battlefield of the Gaze}

The Lacanian Gaze is not a look at, or a look shared. It is outside, beyond the vision of the viewer(s), its invisible force momentarily exposed by the effects of trompe I'oeil. It is also glimpsed through the experience of shame. ${ }^{4}$ (It might be interesting, with more time, to look in more depth at the religious association with an all-seeing, all-judging deity, and to compare Lacan's notion of shame with the role of vergüenza in the Spanish honour code.) But, to return to Lacan, invisible or not, the individual as subject is defined in the field of the Gaze. The feeling of shame or surprise is experienced when we are caught transgressing, either in a voyeuristic attempt to expand our partial vision, or when we respond to something we did not expect to see. (The revelation of Dil's sex in The Crying Game might be a useful example at this point to illustrate the invisible functioning of the field.) The field of the Gaze becomes a battlefield because of the threat it poses to our sense of the self as a subject (see Lacan's sardine can). ${ }^{5}$ Lacan uses repeated military metaphors to describe the power of the Gaze in moulding and confining the dialectical relationship between observer and observed. It is, like the objet petit $a$, an absence, a lack. However, we continue to try, like Freud's nephew with his cotton reel, to control it in the fort-da of the scopic drive. ${ }^{6}$ Here I want to show how, in La muerte de Mikel, cinematography places the conflict between Mikel and his mother firmly in the field of the Gaze.

The field is mapped out in the opening and closing frames. After an initial close-up of the altar (presumably at Mikel's funeral), the focus moves slowly back down the nave, then up to a view from the roof, as if the camera were describing the narrowness of human vision in the context of an allembracing divine gaze. The Catholic Church will act as the film's absolute Other, and therefore as a symbol of the Gaze itself. The all-seeing, allforgiving eye of God will be mediated in the film narrative by the priest, who will urge Mikel's mother to show compassion towards her son. These enigmatic establishing shots are then juxtaposed with our first sight of

truth that, in passing through awareness, does not lie. But one runs after it all the same' (vii).

4 Lacan, The Four Fundamental Concepts of Psycho-analysis, 92, for discussion of Holbein's Ambassadors, and for comments on shame, see page 84.

5 Lacan, 95.

6 Lacan, 105. 
Mikel, shown walking through a wood picking mushrooms, and then sitting, in what we will discover to be uncharacteristically relaxed mode, gazing intently out to sea. Progressing to the closing frames, we find the eerily white face of Mikel's mother, moving into close-up as the credits roll on her fixed stare from the fortress of her house with its iron railings and grilles. This reading takes place with these three shots in mind: the Church, symbolic of the absent, but all-seeing field of the Gaze; the conflict between the partial and mutually exclusive viewpoints of Mikel and his mother, and the way that Mikel's search becomes a progression towards the ultimate prohibition of his gaze, his enigmatic off-screen death.

\section{Incompatible Visions}

The sea Mikel gazes out over is a dream of elsewhere, a poignant Cixousian yearning for a Utopian space where the 'other' will not be condemned to death. ${ }^{7}$ His mother's fixed stare from the barred house, on the other hand, represents the 'other' who will condemn him. She personifies the ideology that comes between Mikel and the impossible object of his gaze, representing one side of a homophobia which crosses political boundaries. Her antipathy to the object of Mikel's gaze (symbolized by the sea, and, later, personified in Fama) is reinforced by the first glimpse we, the other viewers in this relationship, have of her patrolling the coastline.

She polices a boundary separating Mikel from his fantasy life, separating Mikel from the sea. Mikel looks down at the sea from the balcony of his flat as his mother looks up at him, walking along the sea front. Although the viewer is not immediately aware that this is his mother, the extended look they share at this point is challenging-a scopic glove thrown down, perhaps, on the battlefield of the Gaze. The policing role of the mother is later confirmed in her first words, chastising her maid, 'No vuelvas a comportarte así en público', and in the compulsive commentary she provides on her neighbours during Mikel and his wife's obligatory social visit.

Cinematography, then, uses the mother to personify the battle of observer and observed in a field which is patrolled at all times (if we listen to the censorious tones of Mikel's mother) by 'el qué dirán'. The clearest visual indication of this battlefield is in the framing of Mikel, Begoña and the mother in an uneasy triangle, from which the couple exchange silent and hostile glances unnoticed by the mother, who is absorbed in her contemplation and recitation of malicious gossip. The film then traces Mikel's doomed attempt to escape the claustrophobic and controlling social

7 For Hé1ène Cixous' discussion of patriarchal binary oppositions and the way these bring 'death' to those elements they suppress (and which usually represent the feminine), see $L a$ Jeune née (Paris: UGE, 10/18, 1975). 
vision personified by his mother. Narrative jumps will imitate his shaky progress around the perimeters of her territory as the deliberately dislocated montage echoes his struggle to shake off an identity that has been 'laid out' for him by the extremes of Basque ideology represented by his mother and his political comrades.

\section{Optical Méconnaissance and Fantasies of Omnipotence: The Cut- and-Paste Self and/or Other}

Cinema relies on an optical illusion of continuity, an optical méconnaissance. We do not see the gaps between sections of film unless they are deliberately indicated for us by the editing process. The unconscious of the film, then, might be said to lie on the cutting-room floor. In the early stages of $L a$ muerte de Mikel the editing is almost ruthlessly abrupt, as if to show that the unconscious field is, as it were, larger, emphasizing the extent of Mikel's repression. The montage will become slightly more fluid as he moves from a state of infantilized inarticulacy, unable to meet the gaze of others, towards the momentary truce of the shared gaze with Fama, and then on to a more challenging position from which he is able to sustain the looks of the other protagonists and articulate his own desires. Unfortunately, of course, the more challenging he becomes, the more imminent is his own death.

The 'laying out' of identities, both socially and cinematographically, contains a veiled reference to funeral arrangements which is far from coincidental. The editing process of cinema 'lays out' identities on screen in a way which corresponds to Lacan's image of human interaction as masquerade acted out on an invisible screen. Animals in general (according to Lacan) act out the fight for survival using instinctive props or masks (display of feathers and so on). Human beings are said to differ from other animals in that they have greater control over the mask and the way they project themselves. Cinema is not slow to play with this kind of manipulation. Buñuel, for example, has the female protagonist of Un Chien andalou (1928) lay out the clothing of the male protagonist on a bed from which she then withdraws, staring intently, as the image of the infantilized male other is conjured up on the bed. In Saura's Cría cuervos (1975), the teenage daughter, who has just been teased by her younger sister about the lack of response from the 'boy next door', cuts out female magazine models in a mildly obsessive way which suggests she is cutting out a compensatory self she can imagine to be irresistible. This action, cutting and pasting the mask of your choice, is a fantasy of omnipotence, a defence against our all-tooobvious insignificance on the wider social screen. And cinema can remind us that the public display, or ritual, we accept in our daily lives is often stranger than cinematic fiction. In Almodovar's Kika (1993), for example, the self-flagellating penitents 
inserted documentary-style into the film narrative are more disturbing (even) than the fictional exploits of the cinematic protagonists, and the ritual public display of masculinity in the 'geese-dipping' scenes of the San Sebastián Festival reproduced in La muerte de Mikel are quite odd enough to explain why Mikel might experience some confusion over publiclycondoned masculinity. The oddity of geese-dipping brings us back to Lacan's point about ritual display and the role of the mask, or masquerade. Other directors (see the watch scene in Tarantino's Pulp Fiction [1994], or the transvestite-bar scene 'show-down' in Almodovar's Tacones lejanos [1991]) play lightly with the mask, the playful side of masquerade, but Uribe concentrates on its monstrous side.

It is no accident that masquerade and the monstrous often appear simultaneously. A monstrous vision is, for Lacan, the one which 'claims to impose itself as being the only gaze'. ${ }^{8}$ Masquerade, according to Joan Riviere, allows us to disguise aspects of ourselves that might be condemned as monstrous (homosexuality, competitive femininity etc.). ${ }^{9}$ In other words, masquerade is often a response to a monstrous force, whether external or internal, and hence Lacan's description of the mask as the skin thrown over the shield, a form of protection. ${ }^{10}$ The role of masquerade in combat is humorously demonstrated, as suggested above, in Tacones lejanos, while its role in foreplay is shown in the scene where Mikel visits Fama in the club in Bilbao. If the mother's is the monstrous gaze that threatens to annihilate Mikel, then the tentative exchange of looks with Fama provides a moment of truce. It may be worth noting here, although there is not sufficient space to develop this further, that neither Fama, nor Dil in The Crying Game, are 'acting'; both are merely performing themselves for the camera, further indication perhaps of the contortions we perform (the rest of us that is, not Fama or Jaye Davidson) to satisfy the ferocious demands of the sociallycondoned gaze. ${ }^{11}$

\section{The Imaginary and the Oedipal Trajectory}

The scenes from La muerte de Mikel examined so far outline the site of the battlefield of the Gaze, the conflict with the mother, and the liberating, or

8 Lacan, The Four Fundamental Concepts of Psycho-analysis, 113.

9 See chapter 5, 'Defensive Femininity", in The Inner World and Joan Riviere. Collected Papers: 1920-1958, ed. Athol Hughes (London/New York: Karnac Books, 1991).

10 Lacan, The Four Fundamental Concepts of Psycho-analysis, 107.

11 Stanley Kubrick is said to have warned the director of The Crying Game, Neil Jordan, that 'the key role of Dil was probably uncastable', and, according to Giles, Jaye Davidson was found thanks to a recommendation from Derek Jarman. In addition she notes that Davidson had no interest in acting and that the scenes involving Davidson were generally shot 'before the reluctant star had time to think about what was going on', The Crying Game (London: BFI Modern Classics, 1997), 34. 
protective role of masquerade. The next section looks at the role of the Imaginary, associated with the Freudian Oedipal trajectory. La muerte de Mikel tells a contorted Oedipal tale. Mikel's political comrades provide sufficiently officious paternal surrogates. Martin plays Tiresias, correctly predicting that some things are best avoided. Jocasta kills Oedipus, and, rather than symbolically castrating his father, Mikel physically 'castrates' his own wife. ${ }^{12}$ This Oedipal confusion is accentuated by the fact that the men in this film (apart, perhaps, from Fama and the therapist) seem to be singularly 'transitional': they meet in bars, pass by in streets, gather for incomprehensible rituals, whereas the women (Begoña returning confidently from her holiday, Martin's wife, the mother's fierce self-location) seem singularly grounded. However, there is not time to analyse the women here (although the question, Why does Begoña forgive Mikel?' does come to mind, and might be worth further examination with reference to Christianne Olivier's wry comments about what happens to women made out of the male libido). ${ }^{13}$

Mikel's almost painful passivity in the first half of the film would seem to correspond with Joyce McDougall's description of the one possible response to maternal love. She says of clients who become neurotically passive that

Perhaps this giving up, in place of struggling and fighting back [...] is chosen because of the need to protect one's love for the mother. Or perhaps the infants give up the struggle out of sheer exhaustion. They learn to stifle hostile affects and eventually, no longer aware of their rage and violence, they conform to what they realise is expected of them. In other words they become the mother, their mind controlled by hers, and it is perhaps here that the door to psychosomatic explosion stays ajar. ${ }^{14}$

Read with this in mind, the attack on Begoña may be understood as a psychosomatic explosion in which Mikel simultaneously becomes the castrating mother, and pushes open the door to his own cure (in that the attack is so violent that he is sent to seek help). But this explosive act of violence is less typical than the passive stance Mikel takes which is supported by his incursions into the Imaginary. For if masquerade offers public protection, then the space of the Imaginary offers private protection

12 See Marsha Kinder for an alternative to the Oedipal myth, in what she calls the 'preOedipal backstory" of Chrysippus, who was killed by his own mother after having been raped by Oedipus' father (Blood Cinema: The Reconstruction of National Identity in Spain [Berkeley/Los Angeles/London: Univ. of California Press, 1993], 216).

13 Jocasta's Children: The Imprint of the Mother, trans. George Craig (London: Routledge, 1990 [first publ. Paris: Denoel, 1980]), 4.

14 Theatres of the Mind: Illusion and Truth on the Psychoanalytic Stage (London: Free Association Books, 1986), 84 (first publ. as Theatres du Jeu [Paris: Gallimard, 1982]). 
and, like the effect of watching a film in a dark room, the illusion of release from the Gaze. ${ }^{15}$

Mikel is first seen wandering in a wood picking mushrooms. Our vision of him is obscured by leaves which protect him from the external gaze as he picks his mushrooms. The wood, hidden from the controlling gaze of the mother and the censoring presence of 'el qué dirán', has two corresponding locations: the sea, and the bar in Bilbao where he meets Fama. Accordingly, the film might be said to have three spaces of the Imaginary. The wood offers escape from the image of the self in the other, it camouflages Mikel and provides temporary sanctuary. But, as in all good fairy tales, the wood also represents an enclosure that must be left behind. The mushrooms, it transpires, are mainly for Martin, and it is indicative of Mikel's neediness that Martin's wife asks him not to bring so many-last time they could not finish them and she had to throw the remainder out. Looking now in more detail at Martin, he is framed against the sea (Mikel's dream of a Utopian Cixousian elsewhere), and it is to him that Mikel turns for answers, but, like the Stepmother in Snow White, he is not satisfied with the enigmatic response. When Mikel asks Martín to help him understand his problems with women, Martín will only say that there are some things he and Mikel should not discuss if they want to continue being friends.

When Martín turns informer, Mikel is left without his oracle, and with only the wood as a symbolic site of sanctuary. Although he has, in the meantime, found the bar and Fama, he is still tempted back to the wood for a third visit. The editing now links the wood with his mother's home, so that Mikel walks out of the wood straight into the clutches of the 'witchmother'. His potential Gretel (Fama) has already reached a point of resolution, or compromise, in his own battle with 'witches', and Mikel walks alone and blind (reverse Oedipus) into the trap of the maternal home.

\section{Conclusion}

Claire Johnston discusses the way that feminine masquerade is exploited for ideological ends in Anne of the Indies, a children's film in which a woman dresses up as a pirate and is killed. She concludes that 'The radical heterogeneity which her masquerade dramatized has finally been played out and frozen in the ultimate place of radical absence-death itself'. ${ }^{16}$ Mikel's masquerade is perhaps more subtle, but he is equally condemned to

15 Kaja Silvermann highlights the role of the imaginary register in film in 'Historical Trauma and Male Subjectivity', in Psychoanalysis and Cinema, ed. E. Ann Kaplan (London/New York: Routledge, 1990), 110-27, p. 110.

16 'Femininity and the Masquerade: Anne of the Indies', in Psychoanalysis and Cinema, 64-72, p. 68. 
a 'place of radical absence'. His gender is not so obviously and visually exploited. Unlike Fama he does not play with the accessories of feminine masquerade to effect a truce in the fight for survival. Mikel's fight for survival is shown as 'montage'. Cinematography echoes the construction of identities by an external gaze which victimizes and condemns. The positioning of the Catholic Church represents the invisible Gaze, and the fort-da attempt to police the field is symbolized three ways: by the social pressure of 'el que diran'; the police presence that monitors Basque Nationalist sentiment, and, finally, by Mikel's mother.

Cinematography also emphasizes the illusory nature of vision, the gaps in what is seen (mise-en-scène) through which Lacan identifies the field of the Gaze. We see Mikel in a series of different roles-child in enchanted forest, political activist, sexual predator, lover and dead person. The apparatus of cinema is reflected in his mother's fanatical control, prison warder of the totalitarian look, cutting, editing and writing Mikel out of the script. Her final oblique gaze offers aesthetic closure or resolution. But the end result is ideologically frustrating - the viewer is left, aptly enough, in limbo. The film leaves the question of Mikel's sexuality open, and so could itself be accused of sidelining the question of difference, while on the other hand it could be read as a call for enlightened liberal humanist tolerance in the (battle)field of the Gaze. ${ }^{17}$ The viewer is deliberately left to take on the roles the film's enigmatic closure leaves vacant-cutting and pasting, indulging in similar fantasies of interpretative omnipotence, patrolling the boundaries of the cinematic space, and dissecting images for the approval of 'el qué dirán'.

17 Uribe is said to have noted, "personalmente no creo que Mikel sea homosexual; lo que pasa es que en principio todo el mundo es bisexual y después cada uno orienta su sexualidad' (Caparrós Lera, El cine español de la democracia, 257). 